\title{
PENGARUH RISIKO SISTEMATIS DAN EARNING PER SHARE (EPS) TERHADAP HARGA SAHAM PADA PERUSAHAAN FARMASI YANG TERDAFTAR DI BURSA EFEK INDONESIA
}

\author{
Reshma Apriaty ${ }^{1}$, Rinda Sandayani Karhab ${ }^{2}$ \\ ${ }^{1,2}$ Fakultas Ekonomi, Hukum, Politik dan Psikologi \\ Universitas Muhammadiyah Kalimantan Timur \\ *Corresponding author: reshmaapriaty20@gmail.com
}

\begin{abstract}
Abstrak
Penelitian ini bertujuan untuk mengetahui pengaruh variabel risiko sistematis dan Earning Per Share (EPS) secara parsial dan simultan terhadap harga saham pada Perusahaan Farmasi. Periode yang digunakan dalam penelitian ini adalah selama lima tahun, dari tahun 2013 sampai dengan 2017. Penelitian ini merupakan penelitian kuantitatif. Teknik pengumpulan datanya adalah dengan menggunakan purposive sampling, yaitu dilakukan dengan cara memilih subjek yang memenuhi beberapa kriteria. Populasi yang ada pada objek adalah mengambil 6 sampel dari 10 perusahaan yang terdaftar. Teknik penelitian ini menggunakan analisis regresi berganda, uji asumsi klasik (uji normalitas, uji multikolinearitas, uji heterokedastisitas dan uji autokorelasi) serta pengujian hipotesis dengan uji $\mathrm{F}$ (uji simultan), uji t (uji parsial), koefisien determinasi berganda dan analisis korelasi. Penelitian ini menunjukkan bahwa risiko sistematis dan Earning Per Share (EPS) secara simultan memiliki pengaruh yang signifikan terhadap harga saham. Risiko sistematis dan Earning Per Share (EPS) secara bersama-sama mampu menjelaskan naik turunnya harga saham. Earning Per Share (EPS) lebih dominan berpengaruh signifikan terhadap harga saham dengan kontribusi terbanyak terhadap harga saham.
\end{abstract}

Kata kunci: Risiko Sistematis; Laba Per Saham; Harga Saham

\begin{abstract}
This research aimed to determine the effect of systematic risk variables and Earning Per Share (EPS) partially and simultaneously on stock prices in Pharmaceutical Companies. The period used in this study was for five years, from 2013 to 2017. This research is quantitative research. The data collection technique is to use purposive sampling, which is done by selecting subjects that meet several criteria. The population in the object is taking 6 samples from 10 listed companies. This research technique uses multiple regression analysis, classical assumption test (normality test, multicollinearity test, heteroscedasticity test and autocorrelation test) and hypothesis testing with F test (simultaneous test), $t$ test (partial test), multiple determination coefficient and correlation analysis. This study shows that systematic risk and Earning Per Share (EPS) simultaneously have a significant effect on stock prices. Systematic risk and Earning Per Share (EPS) together can explain the ups and downs of stock prices. Earning Per Share (EPS) is more dominantly significant effect on stock prices with the most contribution to stock prices.
\end{abstract}

Keywords: Systematic Risk; Earning Per Share; Stock Price

PENDAHULUAN 
Investasi atau yang sering dikenal dengan penanaman modal merupakan suatu kegiatan yang berkaitan dengan ekonomi untuk mendapatkan dana lebih berupa keuntungan di masa yang akan datang demi mencapai tujuan tertentu. Investasi selalu diikuti adanya risiko karena investor harus memperkirakan berapa besar keuntungan atau penerimaan yang akan di peroleh setelah menanamkan dananya. Risiko yang dihadapi para investor tersebut pada dasarnya ada yang bisa di hindari dan ada yang sulit untuk dihindahi.

Dalam melakukan penanaman modal seperti investasi setiap investor harus teliti dalam mempertimbangkan keuntungan dan kerugian antara return dan risiko serta kinerja keuangan perusahaan tersebut. Dalam hal ini, risiko sistematis yang dilambangkan dengan beta merupakan salah satu risiko yang tidak dapat dihindari dengan diversifikasi karena risiko sistematis yang memiliki sifat selalu berubah mengikuti pergerakan di dalam makro ekonomi sehingga sulit untuk diperkirakan besar kecilnya risiko tersebut. Selain risiko sistematis ada variabel yang juga mempengaruhi tingkat nilai saham yaitu Earning Per Share (EPS).

Sektor farmasi adalah industri yang berdiri sebagai penghasil obat-obatan yang sangat dibutuhkan oleh masyarakat. Pada umumnya permasalahan kesehatan yang terjadi biasanya berhubungan erat dengan ketersediaan obat yang diperlukan. Indonesia menjadi pasar yang paling menjanjikan dibandingkan negara lain. Objek penelitian ini adalah indeks saham yang terdaftar di Bursa Efek Indonesia (BEI) yaitu perusahaan farmasi. Pemilihan objek dikarenakan objek tersebut menarik penulis dimana industri farmasi merupakan salah satu industri yang memiliki target pasar yang besar di Indonesia dan layak untuk dijadikan pilihan investasi jangka panjang. Diperkuat dengan kebutuhan masyarakat akan obat yang tinggi serta harga obat-obatan yang melambung juga akan memikat para investor dikarenakan harga saham perusahaan farmasi juga akan meningkat.

\section{TINJAUAN PUSTAKA}

\section{Pasar Modal}

Pasar modal memiliki peran yang penting untuk perekonomian suatu negara. Salah satu cara efektif untuk mempercepat pembangunan suatu perusahaan agar dapat berkembang merupakan pasar modal. Pengertian pasar modal menurut (Azis et al., 2015) yaitu berbagai asset keuangan yang dapat diperdagangkan dalam jangka waktu lebih dari satu tahun yang bisa diperjualbelikan mulai dari ekuiti (saham), reksadana, instrumen derivative, surat berharga (obligasi) maupun instrumen lainnya disebut pasar modal.

\section{Harga Saham}

Harga penutupan pasar saham selama periode pengamatan untuk setiap jenis saham yang pergerakannya senantiasa diamati oleh para investor. Harga saham yang tinggi akan memberikan keuntungan, seperti hasil keuntungan saham dan capital gain sehingga memudahkan perusahaan mendapatkan dana dari luar perusahaan sehingga harga saham 
menjadi salah satu indikator keberhasilan pengelolaan perusahaan. Menurut Brigham dan Houston (2010) penentu kekayaan pemegang saham adalah harga saham. Memaksimalkan harga saham perusahaan pada satu waktu tertentu akan bergantung pada arus kas didalam perusahaan yang diharapkan akan diterima di masa depan oleh investor.

\section{Risiko Sistematis}

Risiko sistematis atau risiko pasar ialah risiko yang tergantung kepada kondisi makro ekonomi suatu pasar. Menurut Hartono (2014) risiko sistematis merupakan bagian dari risiko sekuritas yang tidak dapat dihilangkan dengan membentuk sekuritas.

\section{H1: Risiko sistematis dan Earning Per Share (EPS) berpengaruh signifikan secara simultan dan parsial terhadap harga saham.}

\section{Earning Per Share (EPS)}

Earning Per Share (EPS) merupakan rasio keuangan yang sering digunakan oleh investor saham atau calon investor saham untuk menjabarkan kemampuan perusahaan menghasilkan laba berdasarkan saham yang dipunyai. Menurut Darmadji dan Fakhruddin (2012) EPS menggambarkan profitabilitas perusahaan yang tergambar pada setiap lembar saham. Semakin tinggi nilai EPS akan menggembirakan pemegang saham karena semakin besar laba yang disediakan untuk investor dan kemungkinan peningkatan jumlah dividen yang diterima oleh investor merupakan rasio yang menunjukkan bagian laba untuk setiap saham.

\section{H2: Earning Per Share (EPS) berpengaruh lebih dominan terhadap harga saham. METODOLOGI}

Penelitian ini menggunakan jenis penelitian kuantitatif yang dianalisis melalui program SPSS 24.00. Populasi dalam penelitian ini yaitu 6 sampel dari 10 perusahaan yang terdaftar di Bursa Efek Indonesia. Data yang digunakan adalah data sekunder, merupakan data yang telah diaudit seperti laporan keuangan perusahaan dengan memakai beberapa analisa untuk menguji data yang telah ditemukan.

\section{Teknik Pengumpulan Data}

Tekhnik pengumpulan data yang digunakan untuk memperoleh data yang diperlukan dengan penelitian ini adalah dokumentasi yakni suatu usaha untuk memperoleh data sekunder melalui pencatatan bukti-bukti yang sudah didokumentasikan seperti laporan keuangan perusahaan.

\section{Populasi dan Sampel}

Populasi dalam penelitian ini adalah perusahaan farmasi yang terdaftar di bursa efek Indonesia yakni terdapat 10 perusahaan. Proses pengambilan sampel dilakukan dengan purposive sampling, yaitu cara pengambilan sampel dengan kriteria yang sudah ditentukan sehingga di dapatkan 6 sampel yang akan digunakan. 


\section{Definisi dan Operasional Variabel Penelitian}

Menurut Sugiyono (2009), variabel adalah segala sesuatu yang berbentuk apa saja yang ditetapkan oleh peneliti untuk dipelajari sehingga diperoleh informasi tentang hal tersebut, kemudian ditarik kesimpulannya. Variabel yang digunakan dalam penelitian ini terdiri dari dua variable yaitu variable independen (X) dan variable dependen (Y). Variabel independen penelitian ini terdiri dari risiko sistematis $\left(\mathrm{X}_{1}\right)$ dan Earning Per Share $\left(\mathrm{X}_{2}\right)$, sedangkan variable dependennya adalah harga saham $(\mathrm{Y})$.

\section{Teknik Analisis Data}

Teknik analisis data yang digunakan dalam penelitian ini adalah analisis regresi linier berganda, yaitu analisis regresi yang mampu menjelaskan hubungan antara variabel terikat (dependent variable) dengan variabel bebas (independent variable) yang lebih dari satu. Analisis linier berganda dalam penelitian ini digunakan untuk mengetahui pengaruh Risiko Sistematis dan Earning Per Share terhadap Harga Saham pada perusahaan farmasi periode 2013-2017. Model dalam penelitian ini dinyatakan sebagai berikut:

$$
\begin{aligned}
& Y=a+ b 1 X 1+b 2 X 2+e \\
& \text { Keterangan: } \\
& \mathrm{Y}=\text { Harga Saham } \\
& \mathrm{a}=\text { Konstanta } \\
& \mathrm{b}_{1}=\text { Koefisien regresi variabel } \mathrm{X}_{1} \\
& \mathrm{~b}_{2}=\text { Koefisien regresi variabel } \mathrm{X}_{2} \\
& \mathrm{x}_{1}=\text { Risiko Sistematis } \\
& \mathrm{x}_{2}=\text { Earning Per Share }(\mathrm{EPS}) \\
& \mathrm{e}=\text { Standar error }
\end{aligned}
$$

\section{HASIL DAN DISKUSI}

\section{Gambaran Umum Perusahaan}

Perusahaan yang bergerak dibidang bisnis komersial yang memiliki target penjualan dalam menyelidiki, memproduksi, pengembangan dan menyalurkan obat, terutama dalam bidang kesehatan. Menjadi salah satu sektor andalan yang diutamakan sebab berperan sebagai penunjang penting dalam perekonomian di masa yang akan datang adalah perusahaan farmasi dan menjadi salah satu investasi paling menjanjikan di Indonesia dalam 5 tahun kedepan karena pertumbuhan rata-rata mencapai 20,6\% per tahun (CAGR). Terkait dengan kebutuhan obat, dengan jumlah penduduk Indonesia yang terus meningkat serta meningkatnya kesadaran masyarakat terhadap kesehatan, potensi peningkatan pengeluaran kesehatan terhadap GDP perkapita turut serta mendorong pertumbuhan industri farmasi nasional. Indonesia berpotensi unggul apabila mengembangkan sektor industri farmasi, herbal, dan kosmetika karena memiliki sumber daya alam yang mampu mendukung proses produksi. 


\section{Hasil Data Penelitian}

Penelitian ini bertujuan untuk menganalisis pengaruh tiap-tiap variabel yang menjadi sampel penelitian pada perusahaan farmasi yang terdaftar di Bursa Efek Indonesia.

Tabel 1

Daftar Perusahaan Farmasi yang terdaftar di Bursa Efek Indonesia

\begin{tabular}{ccl}
\hline No & Kode Saham & \multicolumn{1}{c}{ Nama Perusahaan } \\
\hline 1 & DVLA & Darya Varia Laboratoria Tbk \\
2 & INAF & Indofarma (Persero) Tbk \\
3 & KAEF & Kimia Farma (Persero) Tbk \\
4 & KLBF & Kalbe Farma Tbk \\
5 & MERK & Merck Indonesia Tbk \\
6 & TSPC & Tempo Scan Pasific Tbk \\
\hline
\end{tabular}

Tabel 2

Risiko Sistematis Perusahaan Farmasi Periode 2013-2017

\begin{tabular}{ccccccc}
\hline \multirow{2}{*}{ No } & Kode & \multicolumn{5}{c}{ RISIKO SISTEMATIS (BETA) } \\
& Saham & $\mathbf{2 0 1 3}$ & $\mathbf{2 0 1 4}$ & $\mathbf{2 0 1 5}$ & $\mathbf{2 0 1 6}$ & $\mathbf{2 0 1 7}$ \\
\hline 1 & DVLA & $-8,7350$ & $-1,0019$ & 1,8620 & 2,2844 & 0,4993 \\
2 & SIDO & $-14,9112$ & $-0,5557$ & 0,7936 & $-0,3560$ & 0,2055 \\
3 & KAEF & 5,8673 & 6,4098 & 3,2771 & 14,1041 & $-0,0777$ \\
4 & KLBF & $-5,1883$ & 2,0054 & 2,2487 & 0,9642 & 0,4938 \\
5 & MERK & $-7,0459$ & $-0,6632$ & 1,2355 & 2,3362 & $-0,3253$ \\
6 & TSPC & 3,6951 & $-0,4498$ & 2,9434 & 0,8205 & $-0,3689$ \\
\hline
\end{tabular}

Tabel 3

Earning Per Share Perusahaan Farmasi Periode 2013-2017

\begin{tabular}{ccccccc}
\hline \multirow{2}{*}{ No } & Kode & \multicolumn{5}{c}{ Earning Per Share (EPS) } \\
& Saham & $\mathbf{2 0 1 3}$ & $\mathbf{2 0 1 4}$ & $\mathbf{2 0 1 5}$ & $\mathbf{2 0 1 6}$ & $\mathbf{2 0 1 7}$ \\
\hline 1 & DVLA & 112 & 72.26 & 96.33 & 135.79 & 144.87 \\
2 & SIDO & 27.06 & 27.68 & 29.17 & 32.04 & 35.59 \\
3 & KAEF & 38.63 & 42.24 & 44.81 & 48.15 & 58.84 \\
4 & KLBF & 41 & 44.08 & 42.76 & 49.06 & 51.28 \\
5 & MERK & 7832 & 8101.44 & 6363.64 & 343.4 & 328.99 \\
6 & TSPC & 141 & 128.75 & 155.99 & 119.17 & 120.85 \\
\hline
\end{tabular}

Tabel 4

Harga Saham Perusahaan Farmasi Periode 2013-2017

\begin{tabular}{ccccccc}
\hline \multirow{2}{*}{ No } & Kode & \multicolumn{5}{c}{ HARGA SAHAM } \\
& Saham & $\mathbf{2 0 1 3}$ & $\mathbf{2 0 1 4}$ & $\mathbf{2 0 1 5}$ & $\mathbf{2 0 1 6}$ & $\mathbf{2 0 1 7}$ \\
\hline 1 & DVLA & 2200 & 1690 & 1300 & 1755 & 1960 \\
2 & SIDO & 700 & 610 & 550 & 520 & 545 \\
3 & KAEF & 590 & 1465 & 870 & 2750 & 2700 \\
4 & KLBF & 1250 & 1830 & 1320 & 1515 & 1690 \\
5 & MERK & 9450 & 8000 & 6775 & 9200 & 8500 \\
6 & TSPC & 3075 & 2755 & 1750 & 1970 & 1800 \\
\hline
\end{tabular}


Penelitian ini mengemukakan variabel bebas lebih dari satu, maka analisis yang digunakan adalah analisis regresi linear berganda untuk mengetahui pengaruh antara variabel bebas terhadap variabel terikat. Dari data yang telah diolah menggunakan SPSS data menunjukkan persamaan regresi linear berganda adalah $Y=5.295-0,006 X_{1}+0,481 X_{2}$. Persamaan regresi tersebut dapat dijelaskan bahwa konstanta sebesar 5.295 maksudnya ialah jika risiko sistematis $\left(\mathrm{X}_{1}\right)$ dan EPS $\left(\mathrm{X}_{2}\right)$ maka harga saham $(\mathrm{Y})$ nilainya sebesar 5.295. Dan koefisien regresi variabel risiko sistematis $\left(X_{1}\right)$ sebesar -0,006 dimana koefisien bernilai negatif maknanya adalah tidak terjadi hubungan (searah) antara risiko sistematis dengan harga saham, karena semakin meningkat risiko sistematis maka semakin menurun harga saham. Serta koefisien regresi variabel EPS $\left(\mathrm{X}_{2}\right)$ sebesar 0,481 dimana koefisien bernilai positif maknanya adalah terjadi hubungan positif (searah) antara EPS dengan harga saham, karena semakin meningkat EPS maka semakin meningkat harga saham.

\section{Uji Asumsi Klasik}

Saat dilakukan uji normalitas terlihat bahwa nilai Kolmogorov-Smirnov Test sebesar 0,74 dan nilai signifikasi 0,200. Dengan hasil tersebut maknanya adalah data yang digunakan berdistribusi normal, karena nilai signifikasinya lebih besar dari $\alpha(\alpha=0,05)$ yaitu $0,200>0,05$.

Setelah dilakukan uji multikolinearitas bahwa keempat variabel bebas memiliki nilai tolerance untuk Beta $\left(X_{1}\right)$ 0,979 dan nilai VIF untuk Beta $\left(X_{1}\right)$ 1,021, variabel EPS $\left(\mathrm{X}_{2}\right)$ 0,979 dan VIF untuk EPS $\left(\mathrm{X}_{2}\right)$ 1,021. Masing-masing variabel memiliki nilai VIF < 10 dan nilai tolerance $>0,1$ artinya bahwa data ini tidak mengalami gejala multikolinearitas.

\section{Tabel 5}

Hasil Uji Multikolinearitas

\begin{tabular}{|c|c|c|c|c|c|c|c|c|}
\hline \multirow{4}{*}{\multicolumn{2}{|c|}{ Model }} & \multirow{3}{*}{\multicolumn{2}{|c|}{$\begin{array}{c}\text { Unstandardized } \\
\text { Coefficients }\end{array}$}} & \multirow{4}{*}{$\begin{array}{c}\text { Coeffic } \\
\text { Standardize } \\
\mathrm{d} \\
\text { Coefficients } \\
\text { Beta }\end{array}$} & \multirow[t]{4}{*}{$e^{e n t s} s^{a}$} & \multirow{4}{*}{ Sig. } & \multirow{2}{*}{\multicolumn{2}{|c|}{ Collinearity Statistics }} \\
\hline & & & & & & & & \\
\hline & & & & & & & & \\
\hline & & B & $\begin{array}{l}\text { Std. } \\
\text { Error }\end{array}$ & & & & $\begin{array}{c}\text { Toleranc } \\
\mathrm{e}\end{array}$ & VIF \\
\hline \multirow{3}{*}{1} & (Constant) & 5.295 & .327 & & 16.19 & .000 & & \\
\hline & BETA & -.006 & .008 & -.084 & -.757 & .456 & .979 & 1.021 \\
\hline & EPS & .481 & .067 & .803 & 7.213 & .000 & .979 & 1.021 \\
\hline
\end{tabular}

a. Dependent Variable: HARGA_SAHAM

(Sumber: output SPSS 24.00, data diolah 2019)

Untuk uji heterokedastisitas dengan Scatterplot, data atau titik yang beredar dan menyebar tidak memiliki pola tertentu. Maknanya adalah data tersebut mengalami homokedastisitas, keadaan dimana data tersebut mengalami persamaan varian residual dari sebuah regresi atau tidak terjadi gejala heteroskedastisitas 


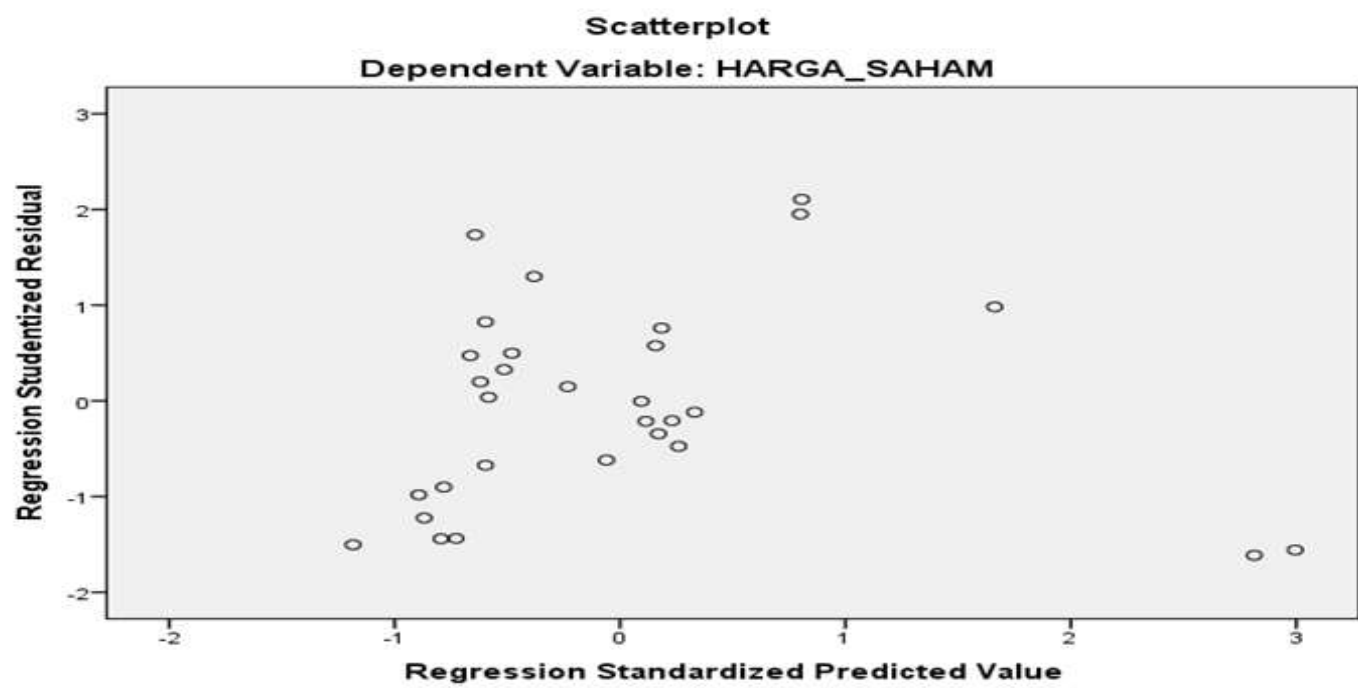

Gambar 1

Hasil Uji Heterokedastisitas

Saat dilakukan uji autokorelasi, nilai DW diketahui 1.998 lebih besar dari batas atas (du) sebesar 1,489 dan kurang dari (4-du) 4-1,489 = 2,510 artinya ialah dapat data tersebut tidak terjadi autokorelasi.

\section{Uji Hipotesis}

Saat dilakukan uji F memiliki signifikasi sebesar 0,000 dimana signifikasi 0,000 < 0,05, artinya bahwa risiko sistematis dan Earning Per Share secara bersama-sama berpengaruh signifikan terhadap harga saham.

Tabel 6

Hasil Uji F (Uji Simultan)

\begin{tabular}{ccccccc}
\hline & & \multicolumn{5}{c}{ ANOVA $^{\mathbf{a}}$} \\
& Model & Sum of Squares & Df & Mean Square & F & Sig. \\
\hline \multirow{4}{*}{1} & Regression & 14.299 & 2 & 7.149 & 27.662 & $.000^{\mathrm{b}}$ \\
& Residual & 6.978 & 27 & .258 & & \\
& Total & 21.277 & 29 & & & \\
\hline
\end{tabular}

a. Dependent Variable: HARGA_SAHAM

b. Predictors: (Constant), EPS, BETA

(Sumber: output SPSS 24.00, data diolah 2019)

Saat dilakukan uji parsial antara variabel risiko sistematis $\left(\mathrm{X}_{1}\right)$ terhadap harga saham (Y) dengan nilai signifikasi 0,456 > 0,05 maknanya adalah risiko sistematis secara parsial tidak berpengaruh signifikan terhadap harga saham. Dan saat dilakukan uji parsial antara variabel EPS $\left(\mathrm{X}_{2}\right)$ terhadap harga saham $(\mathrm{Y})$ nilai signifikasi $0,000<0,05$ maknanya adalah EPS secara parsial berpengaruh signifikan terhadap harga saham Hasil tersebut menunjukkan bahwa Earning Per Share (EPS) mempunyai pengaruh lebih dominan terhadap harga saham. 


\section{Tabel 7}

Hasil Uji t (Uji Parsial)

\begin{tabular}{|c|c|c|c|c|c|c|}
\hline \multicolumn{7}{|c|}{ Coefficients $^{\mathrm{a}}$} \\
\hline & \multirow[t]{2}{*}{ Model } & $\begin{array}{r}\text { Unst } \\
\mathrm{Co}\end{array}$ & $\begin{array}{l}\text { dardized } \\
\text { icients }\end{array}$ & $\begin{array}{l}\text { Standardized } \\
\text { Coefficients }\end{array}$ & \multirow[t]{2}{*}{$\mathrm{T}$} & \multirow[t]{2}{*}{ Sig. } \\
\hline & & B & Std. Error & Beta & & \\
\hline \multirow{3}{*}{1} & (Constant) & 5.295 & .327 & & 16.193 & .000 \\
\hline & BETA & -.006 & .008 & -.084 & -.757 & .456 \\
\hline & EPS & .481 & .067 & .803 & 7.213 & .000 \\
\hline
\end{tabular}

a. Dependent Variable: HARGA_SAHAM

(Sumber: output SPSS 24.00, data diolah 2019)

Saat dilakukan uji $\mathrm{R}^{2}$ adalah sebesar 0,672 atau 67,2\%. Artinya ialah risiko sistematis $\left(\mathrm{X}_{1}\right)$ dan EPS $\left(\mathrm{X}_{2}\right)$ secara bersama-sama menyumbang pengaruh turun naiknya harga saham (Y) sebesar 67,2\%, sedangkan sebesar 32,8\% sisanya dipengaruhi oleh variabel lainnya.

\section{Tabel 8}

\section{Koefisien Determinasi $\left(\mathbf{R}^{2}\right)$}

\section{Model Summary ${ }^{b}$}

\begin{tabular}{ccccc} 
Model & $\mathrm{R}$ & $\mathrm{R}$ Square & Adjusted R Square & $\begin{array}{c}\text { Std. Error of the } \\
\text { Estimate }\end{array}$ \\
\hline 1 & $.820^{\mathrm{a}}$ & .672 & .648 & .50838 \\
\hline
\end{tabular}

a. Predictors: (Constant), EPS, BETA

b. Dependent Variable: HARGA_SAHAM

(Sumber: output SPSS 24.00, data diolah 2019)

Untuk uji koefisien korelasi bahwa pengaruh variabel risiko sistematis dan EPS secara bersama-sama mempunyai hubungan terhadap prestasi (R) sebesar 0,820. Artinya adalah data tersebut hubungannya yang sangat kuat.

\section{Pembahasan}

Hasil pengolahan data penelitian ini menunjukkan bahwa hipotesis pertama dan kedua diterima. Dimana hipotesis pertama memiliki nilai signifikasi 0,000 yang artinya risiko sistematis dan EPS berpengaruh signifikan secara parsial dan simultan terhadap harga saham. Kemudian hipotesis kedua mempunyai nilai sig kecil dari $\alpha$ yaitu $0,000<$ 0,05. Sehingga dapat dinyatakan bahwa EPS berpengaruh lebih dominan terhadap harga saham. Tidak adanya pengaruh risiko sistematis terhadap harga saham kemungkinan disebabkan banyaknya saham di Indonesia yang memang tidak terpengaruh terhadap bebagai isu-isu di pasar karena kebanyakan investor di Indonesia lebih menilai manajemen, kinerja dan keuangan perusahaan dalam penentuan investasinya, sehingga harga saham tidak terpengaruh oleh risiko pasar.

Dapat disimpulkan antara risiko sistematis dengan harga saham memiliki hubungan negatif (tidak searah) disebabkan oleh perusahaan farmasi di Indonesia yang merupakan 
perusahaan yang memiliki nilai jual besar di Indonesia. Selain itu kesadaran masyarakat akan kesehatan akan membuat perusahaan farmasi menjadi salah satu sektor andalan yang diprioritaskan karena berperan sebagai penggerak utama perekonomian di masa mendatang. Sehingga harga saham tidak akan mudah dipengaruhi oleh risiko pasar (risiko sistematis). Sedangkan EPS berpengaruh signifikan positif terhadap harga saham. Hal ini menandakan bahwa hubungan antara Earning Per Share (EPS) dan harga saham menyumbang pengaruh yang bersifat linear dan searah. Dimana jika semakin meningkat harga saham maka semakin besar juga nilai Earning Per Share (EPS) atas investasi tersebut.

\section{SIMPULAN}

Berdasarkan hasil analisis risiko sistematis dan Earning Per Share (EPS) secara simultan memiliki pengaruh signifikasi terhadap harga saham pada perusahaan farmasi di Bursa Efek Indonesia. Earning Per Share (EPS) diketahui secara parsial berpengaruh signifikan terhadap harga saham serta memiliki pengaruh lebih dominan. Saran yang direkomendasikan yaitu bagi pemilik dana yang ingin berinvestasi sebaiknya jangan hanya melihat risiko sistematis dan Earning Per Share (EPS) untuk menilai pergerakan harga saham, karena kemungkinan ada faktor lain yang dapat memberikan pengaruh besar terhadap pergerakan naik turunnya harga saham. Kemungkinan adanya faktor lain yang mempengaruhi harga saham perlu dipertimbangkan oleh peneliti selanjutnya. Saran untuk penelitian selanjutnya adalah menggabungkan satu atau beberapa variabel lainnya yang dianggap relevan dalam mempengaruhi harga saham, serta dapat menambah jumlah sampel penelitian dan mempertimbangkan jangka waktu tahun pengamatannya.

\section{REFERENSI}

Azis, Musdalifah, Sri Mintarti, dan Maryam Nadir. 2015. Manajemen Investasi Fundamental, Teknikal, Perilaku Investor dan Return Saham. Yogyakarta: CV. Budi Utama.

Brigham dan Houston. 2010. Dasar-dasar Manajemen Keuangan. Jakarta: Salemba Empat.

Darmadji, Tjiptono dan Fakhruddin. 2012. Pasar Modal Di Indonesia, Edisi Ketiga. Jakarta: Salemba Empat.

Hartono, Jogiyanto. 2014. Metode Penelitian Bisnis. Edisi Ke-6. Yogyakarta: Universitas Gadjah Mada.

Ida Harianti. 2012. Pengaruh Earning Per Share Dan Ukuran Perusahaan Terhadap Harga Saham Pada Perusahaan Farmasi Di Bursa Efek Indonesia.

Linda Rusli. 2011. Pengaruh Likuiditas dan Profitabilitas Terhadap Harga Saham Perusahaan Manufaktur yang Terdaftar di Bursa Efek Indonesia. 
Roskarina Setianingrum. 2009. Pengaruh Faktor-faktor Fundamental Dan Risiko Sistematik Terhadap Harga Saham (Studi Kasus Pada Perusahaan Manufaktur Yang Listed Di Bursa Efek Indonesia).

Rowland Bismark Fernando Pasaribu. 2008. Pengaruh Variabel Fundamental Terhadap Harga Saham Perusahaan Publik Di Bursa Efek Indonesia.

Sugiyono. 2012. Metode Penelitian Pendidikan Pendekatan Kuantitatif, Kualitatif dan R\&D. Bandung: Alfabeta.

Sugiyono. 2013. Metode Penelitian Pendidikan Pendekatan Kuantitatif, Kualitatif, dan R\&D. Bandung: Alfabeta.

Wulandari, Dwi. 2009. Analisis Pengaruh Variabel-Variabel Fundamental dan Teknikal Terhadap Harga Saham Industri Tekstil. Jurnal Bisnis dan Manajemen 12 (2): 245 260.

Yayuk Sulistyowati. 2012. Pengaruh Earning Per Share (EPS), Price Earning Ratio (PER), Dan Dividend Payout Ratio (DPR) Terhadap Harga Saham (Studi Empiris Pada Perusahaan Food \& Beverages Yang Terdaftar di BEI) 